\title{
Decision To Buy In The Pusat Grosir Surabaya: The Effect of Price and Product Diversity
}

\author{
Mei Indrawati ${ }^{1}$, Woro Utari ${ }^{2}$ \\ \{meiindrawati@uwp.ac.id ${ }^{1}$,woroutari@uwp.ac.id $\left.{ }^{2}\right\}$ \\ ${ }^{1,2}$ Faculty of Economics and Business, Wijaya Putra University
}

\begin{abstract}
In various parts of the city, various shopping centers are scattered, where the products offered in shopping centers are very diverse, from household appliances, fashion, electronics, and so on. Many shopping centers also offer their products in retail ways, but some also offer their products with wholesale sales. As a result of the existence of a retail and wholesale sales system, there will be a difference in product prices between the two sales systems. Pusat Grosir Surabaya (PGS) is a wholesale center located in the city of Surabaya and is the largest wholesale center in East Java. Almost all products are available here which of course can be purchased wholesale or retail, such as clothes, shirts, Muslim clothing, bags, shoes, and other equipment. With the increasing number of wholesale centers in Surabaya, even in East Java, it certainly has the consequence of the existence of very tight competition among the increasingly shopping places. From the things mentioned above, it is very important for a marketer or actor in the shopping center business to find out what factors influence a person's decision to make product purchases in a shopping center. The purpose of this study is: to analyze the effect of price factors and product diversity both partially and simultaneously on buying decisions at the Pusat Grosir Surabaya (PGS), as well as to analyze the price and product diversity that have a dominant influence on buying decisions at the Pusat Grosir Surabaya (PGS). This study uses the independent variable (Independent variable) which consists of variable prices and product diversity. The decision to buy products at PGS is a Dependent variable. The analytical model used to test and prove the hypothesis in this study uses Multiple Linear Regression. The $\mathrm{F}$ test is carried out to determine the effect of independent variables simultaneously. The $t$ test is carried out to determine the effect of partial independent variables. To find out which independent variable is the dominant influence on the dependent variable by looking at the largest regression coefficient. Based on the results of regression analysis, the regression coefficients of all independent variables obtained have a probability value (sig) smaller than 0.05 , which means that partially the price variable and product diversity influence the decision to buy products at PGS. The dominant variable influencing the decision to buy products at PGS is the price variable. The probability of the value (sig) of the $\mathrm{F}$ test in this study $=0,000<0,05$, thus the variable price and product diversity simultaneously influence the decision to buy products at PGS. The conclusion of this study is the price variable and product diversity both partially and simultaneously influence the decision to buy products at PGS and between the price variables and product diversity the dominant influence on the decision to buy products at PGS is price.
\end{abstract}

Keywords: price, product diversity and buying decisions 


\section{Introduction}

As we know in various parts of the city scattered various shopping centers. Where the products offered in shopping centers are very diverse, from household appliances, fashion, electronics, and so on. Many shopping centers also offer their products in retail ways, but some also offer their products with wholesale sales. As a result of the existence of a retail and wholesale sales system, there will be a difference in product prices between the two sales systems.

Pusat Grosir Surabaya (PGS) is a wholesale center located in the city of Surabaya and is the largest wholesale center in East Java. At the Pusat Grosir Surabaya (PGS) there were more than 2000 stands which indicated that the existence of this wholesale center received a positive response from the people of Surabaya and the surrounding areas, especially the people who needed products with low prices and quality. Almost all products are available here which of course can be purchased wholesale or retail, such as clothes, shirts, Muslim clothing, bags, shoes, and other equipment.

With the increasing number of wholesale centers in Surabaya, even in East Java, it certainly has the consequence of the existence of very tight competition among the increasingly shopping places. From the things mentioned above, it is very important for a marketer or actor in the shopping center business to find out what factors influence a person's decision to make product purchases in a shopping center.

There are many factors that influence a person's decision to make a purchase. According to Saputri, 2016, states that several factors that can influence purchasing decisions can be controlled by the seller, but several other factors cannot be controlled. According to Kotler and Keller (2012), purchasing decisions are influenced by basic psychology which plays an important role in understanding how consumers make their purchasing decisions.

In this study, researchers used price factors and product diversity as a determining factor for someone purchasing products at the Pusat Grosir Surabaya (PGS).

The purpose of this study is: to analyze the effect of price factors and product diversity both partially and simultaneously on buying decisions at the Pusat Grosir Surabaya (PGS), as well as to analyze the price and product diversity that have a dominant influence on buying decisions at the Pusat Grosir Surabaya ( PGS).

Some of the previous studies that were used as references in this study include: research from Algrina Agnes Ulus (2013) with the title Marketing Mix influence on Daihatsu Car Purchase Decisions at PT. Astra International Manado. Conclude that products, prices, distribution channels and promotions, both partially and simultaneously influence the Daihatsu Car Purchase Decision at PT. Astra International Manado.

Another previous research was carried out by Hendra Fure (2013) entitled Location, Product Diversity, Price and Service Quality, Influence on Purchasing Interests in Calaca Traditional Health Market, concluding that Location, Product Diversity, Price and Service Quality Affect Interest in Buying Traditional markets with Calaca Health.

Although many factors contribute to the success of a business, today successful companies together have a strong focus on customers and a round of commitment to marketing. Marketing is a social and managerial process which is a means for individuals and groups to obtain what they need and want through the creation and exchange of products and values with other parties (Kotler, 2003). Underlying marketing is a fundamental concept of human needs, which is a statement of hidden feelings. Basic needs shaped by culture and personality are human desires. This desire if supported by purchasing power, becomes a demand. 
Marketing occurs when humans decide to satisfy needs and desires through an exchange process. If the value is actually traded between two parties, the transaction occurs. When a transaction occurs between the same parties, a long-term relationship develops. Developing such relationships with customers through strong social and economic ties is an important target for many marketers.

Consumer decisions in making purchases occur through a very long process and are very complex. Decisions arise from curiosity about the need for a product, whether in the form of goods or services. Several factors that can influence purchasing decisions can be controlled by the seller, but a number of other factors cannot be controlled. According to Kotler and Keller (2012). Purchasing decisions are influenced by basic psychology which plays an important role in understanding how consumers make their purchasing decisions. Everyone who will make a purchase will first choose what is good and in accordance with the wishes before deciding what they want to buy. They will choose according to the character and inner satisfaction that will be obtained later. Besides that they will buy goods and services to meet their needs and desires.

According to Kotler and Keller (2012), there are several elements that concern and consider consumers in making purchasing decisions, namely: (1) product choice; (2) brand choice; (3) channel choices; (4) time of purchase; (5) number of purchases; and (6) payment method.

Tjiptono (2008) said that the purchasing process starts long before someone buys a product and subscribes long after. This encourages producers or marketers to focus on the entire purchasing process rather than just on the buying process: recognizing needs, identifying information, buying decisions and post-purchase behavior.

So the task of marketers is not easy, marketers must understand what is happening in the awareness of buyers starting from the arrival of external stimuli and buyer's purchasing decisions. The buyer characteristics that include culture, social, personal and psychological that influence purchasing behavior as well as how buyers make their purchasing decisions can be seen in the picture below.

\begin{tabular}{|c|c|c|c|c|}
\hline $\begin{array}{l}\text { Marketing } \\
\text { stimulation: } \\
\text { Product } \\
\text { Price } \\
\text { Place } \\
\text { Promotion }\end{array}$ & \begin{tabular}{l}
\multicolumn{1}{c}{ Another } \\
Stimulation \\
\multicolumn{1}{c}{$:$} \\
Economy \\
Technology \\
Politic \\
Culture
\end{tabular} & $\begin{array}{l}\begin{array}{c}\text { Buyers } \\
\text { Characte- } \\
\text { ristics : }\end{array} \\
\text { Culture } \\
\text { Social } \\
\text { Personal } \\
\text { Psycholo- } \\
\text { gical }\end{array}$ & \begin{tabular}{l}
\multicolumn{1}{c}{$\begin{array}{c}\text { Buyer } \\
\text { Decision } \\
\text { Process: }\end{array}$} \\
Introduction \\
to the \\
Problem \\
Information \\
Search \\
Evaluation \\
Decision \\
Post- \\
purchase \\
behavior
\end{tabular} & \begin{tabular}{l}
\multicolumn{1}{c}{$\begin{array}{c}\text { Buyer } \\
\text { Decision: }\end{array}$} \\
Product Choices \\
Brand Choices \\
Choice of \\
Distributors \\
Time of \\
Purchase \\
Amount of \\
Purchases
\end{tabular} \\
\hline
\end{tabular}

Fig. 1. Buyer Behavior Model

Purchasing Process. Marketers must identify who made the purchasing decision, the types of purchasing decisions and the steps in the buying process.

Role of purchase. Five roles that people play in purchasing decisions, namely: Originator: someone who first proposed an idea to buy a product or service; Giver of influence: someone with views or suggestions that influence decisions; Decision maker: someone who decides each 
component of a purchasing decision; Buyer: the person who made the actual purchase and User: someone who consumes or uses the product or service in question.

Purchasing Behavior. Complex buying behavior. When they are involved in purchasing and are aware of significant differences between various brands. These products are rarely bought, expensive, very risky and personal expressions. Dissonance deduction buying behavior. Buyers will shop around to learn what is available but will buy it quite right. Habitual buying behavior. Low consumer involvement and no significant brand differences. Buying behavior that seeks variation. Low consumer involvement, but significant brand differences.

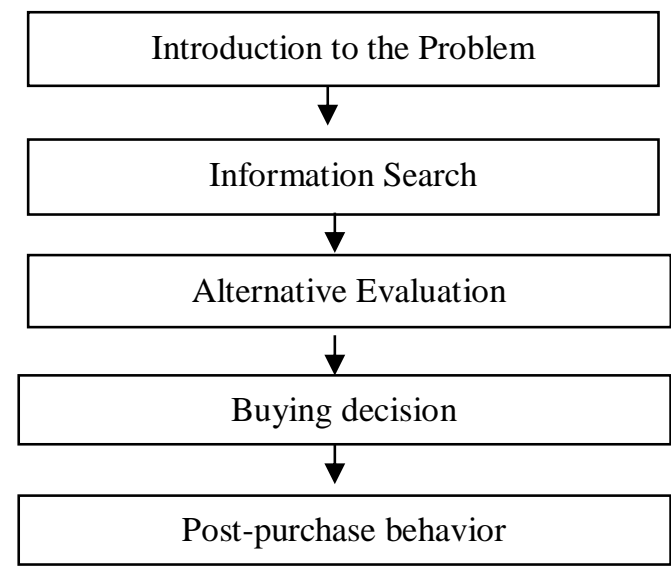

Fig. 2. Stage of the Purchasing Process

Introduction to the Problem. The buying process starts when the buyer recognizes a problem or need.

Information Search. Consumer information sources:

Personal sources: family, friends, neighbors, acquaintances

Commercial sources: advertisements, salespeople, distributors, packaging, brokers

Public sources: mass media, consumer organizations

Source of experience: handling, assessment, product use

Evaluate alternatives. How consumers process competitive brand information and make final judgments, based on awareness and ratio. Consumers try to meet needs, seek benefits from products and view products as a set of attributes with different abilities to provide the benefits sought.

Buying decision. Five sub-purchasing decisions, namely brand decisions, supplier decisions (supplier), quantity decisions, time decisions and payment method decisions.

Post-purchase behavior. After buying a product, consumers will experience a level of satisfaction or dissatisfaction. Satisfaction and dissatisfaction with a product will influence subsequent behavior. If the consumer is satisfied, he will show a higher probability of buying the product again. Satisfied customers also tend to tell good things about the brand to others. Customers who are not satisfied, will react otherwise.

The conceptual framework which is the relationship between variables in this study can be described as follows: 


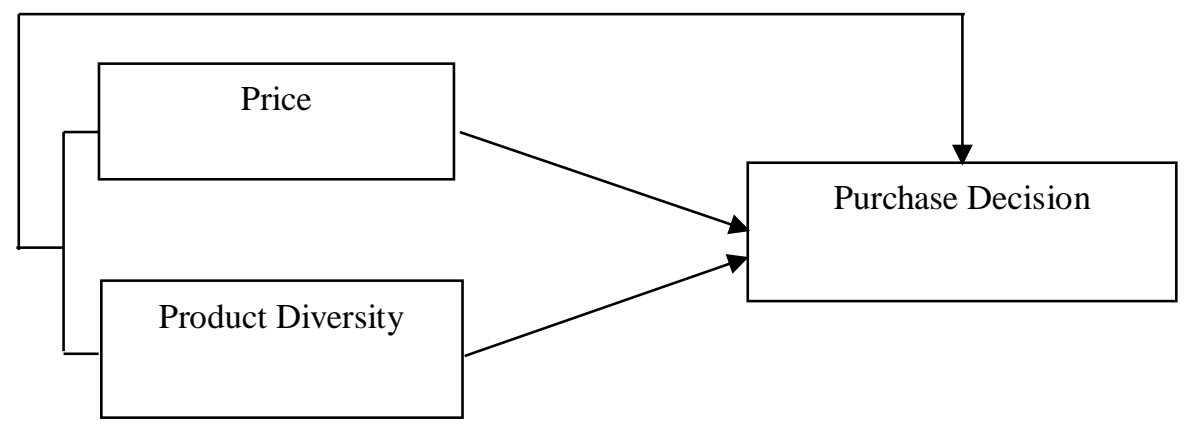

Fig. 3. Research Conceptual Framework

The hypothesis proposed in this study: (1) Price and variety of products partially influence the decision to buy products at the Pusat Grosir Surabaya (PGS) and (2) The prices and diversity of products simultaneously influence the decision to buy products at the Pusat Grosir Surabaya (PGS).

\section{Research Methodology}

This research is a survey research using a questionnaire as a basic data collection tool. This type of research is causal research which aims to explain the causal relationship of the effect of price and product diversity on the decision to buy products at the Pusat Grosir Surabaya (PGS), through testing hypotheses (Malhotra, 1996).

To test and prove the hypothesis in this study using Multiple Linear Regression. To determine the effect of price and product diversity on the decision to buy products at the Pusat Grosir Surabaya (PGS) simultaneously using the F test. Meanwhile, to determine the effect partially using the $\mathrm{t}$ test.

The population in this study were all buyers who made product purchasing decisions at the Pusat Grosir Surabaya (PGS). While the sample in this study are some buyers who make product purchase decisions at Pusat Grosir Surabaya (PGS). This research was conducted in May 2018 until June 2018. Respondents were chosen and determined intentionally at the Pusat Grosir Surabaya (PGS). Samples were determined purposively, namely the determination of samples based on certain considerations from researchers, namely buyers who make product purchase decisions at the Pusat Grosir Surabaya (PGS), and buyers meet the following criteria: aged over 18 years, buying products with their own money and individuals individual. Accidentally, product buyers at Pusat Grosir Surabaya (PGS) have been determined as research samples, who have met these predetermined criteria, which incidentally researchers met at the Pusat Grosir Surabaya (PGS) can be used as research respondents. The research respondents were determined to be fifty people.

The variables used are price, product diversity and product purchasing decisions at the Pusat Grosir Surabaya (PGS). Independent variable (Independent variable) consists of variable prices and product diversity at the Pusat Grosir Surabaya (PGS). The decision to purchase products at the Pusat Grosir Surabaya (PGS) as a dependent variable (Dependent variable).

1. Price is the perception of people who buy products at the Pusat Grosir Surabaya (PGS), which is about the amount of value that consumers exchange for the benefits of owning or using a product or service. Price indicators in this study include: affordable prices 
(X11), uniform prices of similar products (X12), prices competing with other wholesale centers (X13).

2. Product diversity is the perception of people who buy products at the Pusat Grosir Surabaya (PGS) about a variety of products at the Pusat Grosir Surabaya (PGS), namely the availability of various kinds of products (X21), the availability of various products with various quality (X22), availability of various kinds of products with various prices (X23).

3. The decision to make a product purchase in the availability of various kinds of products is a person's behavior in terms of deciding to purchase products at the Pusat Grosir Surabaya (PGS), where the decision is based on: the desire to try to buy products at the Pusat Grosir Surabaya (PGS) Y11) and the desire to compare it with other wholesale centers (Y12).

This study used a questionnaire as an instrument. Respondents were asked to give their responses by choosing one of the chosen answers. These answers are quantified and measured using a 5-point Likert scale. Westbrook and Oliver, 1991 in Kozak and Rimmington (2000) say the Likert scale has a high value of reliability and validity.

The main tool for collecting data in this study is a questionnaire, which was distributed to respondents who the researchers considered had met the criteria as respondents. Interviews, Documentation, Observation, Literature studies are also conducted to find data that has to do with the problem being studied.

The research questionnaire was made to obtain information relevant to the research objectives. A good data collection tool, can be used to collect data that is more objective and able to test the research hypothesis. Two basic requirements to be stated as good data collection tools are validity and reliability.

\section{Result and Discussion}

The conditions or characteristics of buyers who make product purchase decisions at the Pusat Grosir Surabaya (PGS) that have been tabulated can be summarized as in the tables below.

Table 1. Characteristics of Respondents by Gender

\begin{tabular}{cccc}
\hline No & Gender & Total & Percentage \\
\hline 1 & Men & 10 & $20 \%$ \\
2 & Women & 40 & $80 \%$ \\
\hline
\end{tabular}

Source: processed primary data

Table 2. Characteristics of Respondents by Level of Education

\begin{tabular}{lcc}
\hline Educational level & Total & Percentage \\
\hline Above Bachelor & 4 & $8 \%$ \\
Bachelor & 15 & $30 \%$ \\
High School & 12 & $24 \%$ \\
Junior High School & 10 & $20 \%$ \\
Elementary School & 5 & $10 \%$ \\
Not Graduated from Elementary School & 4 & $8 \%$ \\
\hline
\end{tabular}

Source: processed primary data 
Table 3. Characteristics of Age-Based Respondents

\begin{tabular}{cll}
\hline Age & Total & Percentage \\
\hline $18-30$ years old & 15 & $30 \%$ \\
$31-35$ years old & 13 & $26 \%$ \\
$36-40$ years old & 8 & $16 \%$ \\
$41-45$ years old & 8 & $16 \%$ \\
$46-50$ years old & 4 & $8 \%$ \\
Above 50 years old & 2 & $4 \%$ \\
\hline
\end{tabular}

Source: processed primary data

Table 4. Characteristics of Respondents by Job

\begin{tabular}{lll}
\hline Job & Total & Percentage \\
\hline Government employees & 8 & $16 \%$ \\
Private & 18 & $36 \%$ \\
Entrepreneur & 20 & $40 \%$ \\
Does not work & 4 & $8 \%$ \\
\hline
\end{tabular}

Source: processed primary data

Table 5. Characteristics of Respondents by Income

\begin{tabular}{lll}
\hline Income & Total & Percentage \\
\hline 1 Million - 3 Million & 16 & $32 \%$ \\
3,1 Million - 5 Million & 18 & $36 \%$ \\
Above 5 Million & 16 & $32 \%$ \\
\hline
\end{tabular}

Source: processed primary data

This study used a questionnaire to collect research data. To find out the validity of the questionnaire using the Corrected Item-total Correlation formula from Pearson. The testing criteria are carried out if the correlation of each factor is 0.30 and above, the factor is a strong construct, on the contrary if the correlation price is below 0.30 then it can be concluded that the instrument item is invalid, so it must be repaired or discarded (Azwar, 1992 in Mei Indrawati, 2012).

Table 6. Test the Validity of the Questionnaire

\begin{tabular}{llll}
\hline Variable & Item Number & $\mathbf{R}_{\text {total }}$ & Conclusion \\
\hline \multirow{2}{*}{ Price Factor } & 1 & 0.789 & Valid \\
& 2 & 0.865 & Valid \\
& 3 & 0.840 & Valid \\
& 1 & 0.871 & Valid \\
Product Diversity Factor & 2 & 0.799 & Valid \\
& 3 & 0.711 & Valid \\
Decision to make product & 1 & 0.732 & Valid \\
purchases & 2 & 0.754 & Valid \\
\hline Source: processed primary & data & &
\end{tabular}

Source: processed primary data 
From the results of the validity test, it appears that all items of each variable have $r$ above 0.3 , thus it can be concluded that all items of each variable are valid, so that all items of each variable can be used for research data collection and analysis / testing more go on.

Based on the reliability test, the Cronbrach Alpha coefficient values obtained all variables above 0.6 , so that the measurement of the three variables is reliable. So that the third item of the overall variable can be used for further research data retrieval.

Table 7. Test Reliability of the Questionnaire

\begin{tabular}{lll}
\hline Variable & $\alpha$ & Conclusion \\
\hline Price Factor $\left(\mathrm{X}_{1}\right)$ & 0.809 & Reliable \\
Product Diversity Factor $\left(\mathrm{X}_{2}\right)$ & 0.823 & Reliable \\
Decision to make product purchases in PGS (Y) & 0.869 & Reliable \\
\hline
\end{tabular}

Source: processed primary data

The results of the research on the variables in this study can be described in succession based on the indicators of each variable can be seen in the following table:

Table 8. Data Factor Price Variable Description (X1)

\begin{tabular}{|c|c|c|c|c|c|c|c|c|c|c|c|}
\hline \multirow{3}{*}{ No } & \multirow{3}{*}{ Information } & \multicolumn{10}{|c|}{ Assessment } \\
\hline & & \multicolumn{2}{|c|}{$\begin{array}{l}\text { Strongly } \\
\text { Agree }\end{array}$} & \multicolumn{2}{|c|}{ Agree } & \multicolumn{2}{|c|}{$\begin{array}{l}\text { Simply } \\
\text { Agree }\end{array}$} & \multicolumn{2}{|c|}{ Disagree } & \multicolumn{2}{|c|}{$\begin{array}{l}\text { Strongly } \\
\text { Disagree }\end{array}$} \\
\hline & & $\mathrm{F}$ & $\%$ & $\mathrm{~F}$ & $\%$ & $\mathrm{~F}$ & $\%$ & $\mathrm{~F}$ & $\%$ & $\mathrm{~F}$ & $\%$ \\
\hline 1 & Affordable prices $\left(\mathrm{X}_{11}\right)$ & 30 & 60 & 18 & 36 & 2 & 4 & 0 & 0 & 0 & 0 \\
\hline 2 & $\begin{array}{l}\text { Uniformity prices of similar products } \\
\left(\mathrm{X}_{12}\right)\end{array}$ & 21 & 42 & 25 & 50 & 3 & 6 & 1 & 2 & 0 & 0 \\
\hline 3 & $\begin{array}{l}\text { Prices compete with other wholesale } \\
\text { centers }\left(\mathrm{X}_{13}\right)\end{array}$ & 33 & 66 & 16 & 32 & 0 & 0 & 1 & 2 & 0 & 0 \\
\hline
\end{tabular}

Source: processed primary data

a. Respondents' answers to affordable prices had an effect on buying decisions at PGS, most respondents were 30 respondents $(60 \%)$ strongly agreed, 18 respondents $(36 \%)$ agreed.

b. Respondents' answers to their opinions on the uniformity of prices of similar products had an effect on buying decisions at PGS, most respondents were 21 respondents (42\%) strongly agreed, 25 respondents (50\%) agreed and 3 respondents (6\%) agreed enough.

c. Respondents' answers about product prices at PGS competing with other wholesale centers will influence the buying decisions at PGS, most of the respondents, 33 respondents $(66 \%)$ strongly agree, 16 respondents (32\%) agree. 
Table 9. Description of variable data Product diversity (X2)

\begin{tabular}{|c|c|c|c|c|c|c|c|c|c|c|c|}
\hline \multirow[t]{2}{*}{ No } & \multirow[t]{2}{*}{ Information } & \multicolumn{2}{|c|}{$\begin{array}{l}\text { Assessment } \\
\text { Strongly } \\
\text { Agree }\end{array}$} & \multicolumn{2}{|c|}{ Agree } & \multicolumn{2}{|c|}{$\begin{array}{l}\text { Simply } \\
\text { Agree }\end{array}$} & \multicolumn{2}{|c|}{ Disagree } & \multicolumn{2}{|c|}{$\begin{array}{l}\text { Strongly } \\
\text { Disagree }\end{array}$} \\
\hline & & $\mathrm{F}$ & $\%$ & $\mathrm{~F}$ & $\%$ & F & $\%$ & $\mathrm{~F}$ & $\%$ & $\mathrm{~F}$ & $\%$ \\
\hline 1 & $\begin{array}{l}\text { Availability of various products } \\
\left(\mathrm{X}_{21}\right)\end{array}$ & 35 & 70 & 15 & 30 & 0 & 0 & 0 & 0 & 0 & 0 \\
\hline 2 & $\begin{array}{l}\text { Availability of various kinds of } \\
\text { products with various quality }\left(\mathrm{X}_{22}\right)\end{array}$ & 32 & 64 & 17 & 34 & 1 & 2 & 0 & 0 & 0 & 0 \\
\hline 3 & $\begin{array}{l}\text { Availability of various kinds of } \\
\text { products with various prices }\left(\mathrm{X}_{23}\right)\end{array}$ & 25 & 50 & 20 & 40 & 5 & 10 & 0 & 0 & 0 & 0 \\
\hline
\end{tabular}

Source: Processed primary data

a. Respondents' answers about the availability of various types of products (X21) affect the buying decisions at PGS, most of the respondents, 35 respondents $(70 \%)$ stated strongly agree, 15 respondents $(30 \%)$ agreed.

b. Respondents' answers about the availability of various types of products with various types of quality (X22) influence the buying decisions at PGS, most of the respondents, namely 32 respondents $(64 \%)$ stated strongly agree, 17 respondents $(34 \%)$ agreed and 1 respondent (2\%) states quite agree.

c. Respondents' answers about the availability of various types of products with various prices (X23) affect the buying decisions at PGS, most of the respondents were 25 respondents $(50 \%)$ who strongly agreed, 20 respondents $(40 \%)$ agreed and 5 respondents $(10 \%))$ states quite agree.

Table 10. Description of Variable Data Decision to Make Purchases at PGS (Y)

\begin{tabular}{|c|c|c|c|c|c|c|c|c|c|c|c|}
\hline \multirow[t]{2}{*}{ No } & \multirow[t]{2}{*}{ Information } & \multicolumn{2}{|c|}{$\begin{array}{l}\text { Assessment } \\
\text { Strongly } \\
\text { Agree }\end{array}$} & \multicolumn{2}{|c|}{ Agree } & \multicolumn{2}{|c|}{$\begin{array}{l}\text { Simply } \\
\text { Agree }\end{array}$} & \multicolumn{2}{|c|}{ Disagree } & \multicolumn{2}{|c|}{$\begin{array}{l}\text { Strongly } \\
\text { Disagree }\end{array}$} \\
\hline & & $\mathrm{F}$ & $\%$ & $\mathrm{~F}$ & $\%$ & $\mathrm{~F}$ & $\%$ & $\mathrm{~F}$ & $\%$ & $\mathrm{~F}$ & $\%$ \\
\hline 1 & $\begin{array}{l}\text { The desire to try to buy products } \\
\text { at the Pusat Grosir Surabaya } \\
\text { (PGS) (Y11) }\end{array}$ & 32 & 64 & 17 & 34 & 1 & 2 & 0 & 0 & 0 & 0 \\
\hline 2 & $\begin{array}{l}\text { The desire to compare it with } \\
\text { other wholesale centers ( } \mathrm{Y} 12)\end{array}$ & 30 & 60 & 20 & 40 & 0 & 0 & 0 & 0 & 0 & 0 \\
\hline
\end{tabular}

Source: processed primary data

a. Respondent's answer about the desire to try to buy products at the Pusat Grosir Surabaya (PGS) (Y11), most of the respondents were 32 respondents (64\%) who strongly agreed, 17 respondents (34\%) agreed and 1 respondent $(2 \%)$ stated enough agree.

b. Respondent's answer about the desire to compare it with other wholesale centers (Y12), the majority of respondents were 30 respondents (60\%) strongly agree, 20 respondents (40\%) agreed. 
Table 11. Results of Regression Calculation

\begin{tabular}{|c|c|c|c|c|c|}
\hline \multirow[t]{2}{*}{ Model } & \multicolumn{2}{|c|}{$\begin{array}{l}\text { Unstandardized } \\
\text { Coefficients }\end{array}$} & \multirow{2}{*}{$\begin{array}{c}\text { Standardized } \\
\text { Coefficients } \\
\text { Beta }\end{array}$} & \multirow[t]{2}{*}{$\mathrm{t}$} & \multirow[t]{2}{*}{ Sig. } \\
\hline & B & Std. Error & & & \\
\hline 1 (Constant) & 2.961 & 1.817 & & 1.982 & .053 \\
\hline Price of product & .804 & .209 & .713 & 3.597 & .002 \\
\hline diversity & .711 & .211 & .612 & 3.133 & .003 \\
\hline
\end{tabular}

Source: processed primary data

From that table, the following multiple linear regression equations can be arranged: $\mathrm{Y}=$ $2.961+0.804 \mathrm{X} 1+0.711 \mathrm{X} 2+\mathrm{e}$

a. The constant $(\alpha)$ of 2.961 means that by assuming all independent variables are equal to 0 , then the decision to make a purchase at PGS (Y) is 2.961.

b. The price variable regression coefficient (b1) of 0.804 means that for every one percent price change, the decision to make a purchase at PGS will increase by 0.804 percent. In this case other factors that influence the decision to make a purchase at PGS are considered permanent.

c. The regression coefficient of product diversity variable (b2) of 0.711 means that every change in one percent of product diversity, the decision to make purchases at PGS will increase by 0.711 percent, other factors that influence the decision to make purchases at PGS are considered permanent.

Table 12. Coefficient of Determination

\begin{tabular}{lcrrrr}
\hline Model & $\mathrm{R}$ & R Square & $\begin{array}{c}\text { Adjusted R } \\
\text { Square }\end{array}$ & $\begin{array}{c}\text { Std. Error of the } \\
\text { Estimate }\end{array}$ & Durbin-Watson \\
\hline 1 & $.949^{\mathrm{a}}$ & .901 & .798 & & 2.011 \\
\hline
\end{tabular}

a. Predictors: (Contant), Price, Product Diversity

b. Dependent Variables: Buying Decision

Source: processed primary data

The value of $\mathrm{R}=0.949$ shows the relationship between the two independent variables with the dependent variable is very close (a very strong relationship). R2 or determination coefficient value of 0.901 or $90.1 \%$, this means that $90.1 \%$ of the variation in decisions to make purchases at PGS can be explained by variations of both independent variables namely price and product diversity, while the remaining $9.9 \%$ is explained by reason - Other causes outside the model.

Based on the results of regression analysis, the testing of the regression coefficients of all independent variables (price and product diversity) has a probability value (sig) smaller than 0.05, which means that partially the price and diversity of products affect the decision to make purchases at PGS. From the results of the $t$ test, it can be explained that the variable that has the dominant influence on the decision to make a purchase at PGS is the price variable.

Table 13. -F Test Results

\begin{tabular}{llllll}
\hline Model & Sum of Squares & df & Mean Square & F & Sig \\
\hline 1 & 418.973 & 2 & 214.483 & 24.317 & $.000^{\text {a }}$ \\
Regression & 257.937 & 48 & 9.563 & & \\
Residual & 676.910 & 50 & & & \\
Total & & & & & \\
\hline
\end{tabular}

a. Predictors: (Contant), Price, Product Diversity 
b. Dependent Variables: Buying Decision

Source: processed primary data

In the table above the probability value ( $\mathrm{sig}$ ) in this study $=0,000<0.05$, thus the price and product diversity simultaneously influence the decision to make purchases at the PGS (Pusat Grosir Surabaya).

\section{Conclusion}

The price and diversity of products, both partially and simultaneously influence the decision to make purchases at the PGS (Pusat Grosir Surabaya) and between product prices and diversity that have a dominant influence on the decision to make purchases at PGS (Pusat Grosir Surabaya) are prices.

\section{REFERENCES}

[1] Bordas, E. 1994. Competitiveness of Tourist Destinations in Long Distance Markets. Tourist Review 3, 3 -9.

[2] Engel, J.F., Blackwell, R.D. \& Miniard, P.W. 1992. Consumer Behavior. Sixth Edition. The Dryden Press. Chicago.

[3] Fure, Hendra. 2013. Lokasi, Keberagaman Produk, Harga dan Kualitas Pelayanan Pengaruhnya Terhadap Minat Beli Pada Pasar Tradisional Bersehati Calaca. Jurnal EMBA Vol. 1 No. 3, $273-283$.

[4] Heung, V.C.S. \& Chu, R. 2000. Important Factors Affecting Hong Kong Consumer's Choice of a Travel Agency for All-Inclusive package Tours. Journal of Travel Research Vol. 39, 52 59.

[5] Indrawati, Mei. 2012. Pengaruh Faktor Pribadi dan Faktor Sosial Terhadap Keputusan Melakukan Kunjungan Wisata ke Obyek Wisata Bahari Lamongan (WBL).. Jurnal Neo-Bis Vol. 6 No. 2, $170-188$.

[6] Kotler, P. 2003. Marketing Management. Eleventh Edition. Pearson Education, Inc. New Jersey.

[7] Kozak, M. \& Rimmington, M. 2000. Tourist Satisfaction with Mallorca, Spain, as on OffSeason Holiday Destination. Journal of Travel Research Vol. 38, 260 - 269.

[8] Loudon, D.L. \& Bitta, A.J.D. 1993. Consumer Behavior. Fourth Edition. McGraw - Hill International Edition. New York.

[9] Malhotra, N.K. 1996. Marketing Research : An Applied Orientation. Prentice-Hall International, Inc. New Jersey.

[10] Nasir, M. 1985. Metode Penelitian. Cetakan ketiga. Ghalia Indonesia.

[11] Ulus, Algrina Agnes. 2013. Bauran Pemasaran Pengaruhnya Terhadap Keputusan Pembelian Mobil Daihatsu Pada PT. Astra Internasional Manado. Jurnal EMBA Vol. 1 No. 4, 1134 1144.

[12] Zahara, Zakiyah. 1998. Analisis Faktor-Faktor yang Mempengaruhi Konsumen Dalam Membuat Keputusan Pembelian Kain Songket di Kotamadya Palembang. Tesis. Program Pascasarjana Universitas Brawijaya. Malang.

[13] Bhattacharya, A. \& Friedman, H.H. 2001. Using "Smart" Pricing to Increase Profits and Maximize Customer Satisfaction. National Public Accountant Vl. 46, 34 - 38.

[14] Brooks, R. 2000. Why Loyal Employees and Customers-Improve the Bottom Line. Journal for Quality \& Participation, Vol. 23, $40-44$. 
[15] Campbell, M.C. 1999. Perceptions of Price Unfairness : Antecedents and Consequences. Journal of Marketing Research Vol. XXXVI, 187 - 199.

[16] Cravens, D.W. 1997. Strategic Marketing. The McGraw-Hill Companies, Inc., USA.

[17] Gerstner, E. 1985. Do Higher Prices Signal Higher Quality ? Journal of Marketing Research Vol. XXII, $209-215$.

[18] Keegan, W.J. 1999. Global Marketing Management. Sixth Edition. Prentice -Hall, Inc. New Jersey.

[19] Kotler, P.2003. Marketing Management. Eleventh Edition. Pearson Education, Inc. New Jersey.

[20] Rangkuti, F. 2001. Riset Pemasaran. PT. Gramedia Pustaka Utama. Jakarta. 